\title{
OCENA STANU BEZPIECZEŃSTWA PRACY NA RUSZTOWANIACH BUDOWLANYCH NA PODSTAWIE PROTOKOKÓW KONTROLI POWYPADKOWEJ
}

\author{
Marek Sawicki, Mariusz Szóstak ${ }^{\bowtie}$ \\ Wydział Budownictwa Lądowego i Wodnego, Politechnika Wrocławska, Wrocław
}

\begin{abstract}
STRESZCZENIE
W artykule podjęta została próba oceny stanu bezpieczeństwa pracy na stanowiskach, w których wykorzystuje się rusztowania budowlane, zaproponowanych współczynników możliwości zaistnienia wypadku przy pracy. Współczynniki określono według danych zgromadzonych w protokołach kontroli powypadkowych z wypadków przy pracy w budownictwie z udziałem rusztowań budowlanych, do których doszło na terenie 5 polskich województw w latach 2008-2017. W prowadzonych badaniach analizie poddano wpływ następujących parametrów: wiek osoby poszkodowanej, godzina wypadku, w której doszło do wypadku, rodzaj prowadzonych robót, typ rusztowania, na którym doszło do wypadku, oraz wysokość, z której doszło do upadku osoby poszkodowanej. Do oceny stanu bezpieczeństwa pracy na rusztowaniach zaproponowano cząstkowe współczynniki możliwości zaistnienia sytuacji niebezpiecznej oraz ogólny współczynnik zagrożenia. Otrzymane wyniki pozwoliły na opracowanie formularza wstępnej oceny bezpieczeństwa rusztowania budowlanego wykorzystującego zaproponowane cząstkowe współczynniki zagrożenia, pozwalającego na wstępną ocenę prawdopodobieństwa zaistnienia zdarzenia wypadkowego na rusztowaniach budowlanych w odniesieniu do populacji badanych wypadków przy pracy oraz populacji rusztowań budowlanych.
\end{abstract}

Słowa kluczowe: rusztowania budowalne, wypadki przy pracy, bezpieczeństwo pracy

\section{WSTĘP}

Budownictwo jest jednym z czołowych działów gospodarki o największej liczbie wypadków przy pracy zarówno w Polsce, jak i na świecie (Hoła, Nowobilski, Szer i Szer, 2017; Jazayeri i Dadi, 2017; Jaafar, Arifin, Aiyub, Razman i Kamaruddin, 2018). Z analizy danych statystycznych opublikowanych przez Główny Urząd Statystyczny Polski za 2017 rok wynika, że liczba wszystkich wypadków przy pracy, ogółem we wszystkich sekcjach gospodarki, wyniosła ponad 88 tysięcy, gdzie zginęło 270 pracowników, w tym aż 58 osób w budownictwie. Na podstawie danych staty- stycznych można stwierdzić, że w 2017 roku wskaźnik wypadkowości w polskim budownictwie wyniósł 6,01 osób poszkodowanych na 1000 pracujących. Spośród wszystkich sekcji gospodarki narodowej budownictwie znajduje się na 8 . miejscu pod względem wartości wskaźnika częstości wypadków. Niestety wysoki wskaźnik wypadków lekkich, ciężkich i śmiertelnych klasyfikuje branżę budowlaną w czołówce najbardziej narażonych na wypadki sekcji. Należy jednak zauważyć kształtowanie się tendencji spadkowej tych wskaźników w ostatnich kilku latach. W ostatnich 10 latach (od 2008 do 2017 roku) wskaźnik wypadków ogółem w polskim budownictwie zmalał o $50 \% \mathrm{w}$ stosunku do

\footnotetext{
$\bowtie$ mariusz.szostak@pwr.edu.pl
} 
wskaźnika osiągniętego w 2008 roku, który wynosił aż 12,26 osób poszkodowanych na 1000 pracujących (GUS, 2018).

Badania dotyczące stanu wypadkowości i przyczyn wypadków przy pracy w polskim budownictwie prowadzone są przez wielu badaczy. I tak np.:

- w pracy Hoły (2008) przedstawiono obszerną metodykę analizy i oceny wypadkowości w budownictwie,

- celem badań prowadzonych przez Drozda (2016) było wskazanie znaczenia cech terenu budowy i zachowań pracowników w definiowaniu okoliczności wypadku przy pracy,

- w pracy Hoły (2016) podjęta została próba przedstawienia głównych zagadnień ochrony zdrowia i życia pracowników powiązanych z procesem inwestycyjnym w budownictwie.

\section{MATERIAt I METODY}

Rusztowania budowlane to tymczasowe konstrukcje budowlane, z których mogą być wykonywane prace na wysokości, służące do utrzymywania osób, materiałów oraz sprzętu. Rusztowania budowlane wykorzystywane są w budownictwie jako rusztowania robocze lub ochronne. Praca na wysokości, w szczególności na rusztowaniach, jest jedną z najbardziej wypadkowych czynności na terenie budowy. Upadki z rusztowań budowlanych stanowią ponad 38\% wszystkich upadków z wysokości, co oznacza, że co 3. upadek z wysokości następuje z rusztowania (Szóstak, 2018).

Informacje o wypadkach przy pracy znajdują się w dokumentach sporządzanych przez inspektorów Państwowej Inspekcji Pracy w Polsce, w protokołach kontroli. Protokoły kontroli zawierają informacje na temat poszczególnych wypadków przy pracy, ich okoliczności oraz przyczyn. Przeprowadzona przez autorów artykułu wstępna analiza zgromadzonych danych i studia literaturowe wykazała istnienie zależności między zaistniałymi wypadkami opisanymi w protokołach kontroli a parametrami fizjologicznymi organizmu ludzkiego zmieniającymi się w kolejnych okresach dnia pracy i życia. Analiza osób poszkodowanych $\mathrm{w}$ wypadkach przy pracy $\mathrm{w}$ budownictwie z udziałem rusztowań budowlanych, do których doszło na terenie 5 polskich województw w latach 2010-
-2015, pozwoliła na sformułowanie profilu zawodowego osoby poszkodowanej, w której udowodniono, że parametry, takie jak: wiek poszkodowanego, pora dnia w momencie zaistnienia wypadku, pora roku, w jakiej nastąpił wypadek, mają wpływ na liczbę zdarzeń wypadkowych (Sawicki i Szóstak, 2018).

W prowadzonych badaniach analizie poddano 219 osób poszkodowanych w wypadkach przy pracy z udziałem rusztowań budowlanych, które zdarzyły się w 5 województwach Polski (dolnośląskim, lubelskim, lubuskim, mazowieckim oraz wielkopolskim) w latach 2008-2017. Niniejszy artykuł stanowi kolejny etap prowadzonych badań mających na celu określenie kolejnych istotnych zależności między analizowanymi danymi. Analizowane dane w różnym stopniu wypływają na liczbę zdarzeń wypadkowych.

W artykule w odniesieniu do liczby wypadków przy pracy analizie poddano parametry, takie jak: wiek osoby poszkodowanej (w), godzina wypadku, w której doszło do wypadku $(g)$, rodzaj prowadzonych robót $(r)$, typ rusztowania, na którym doszło do wypadku $(t)$, wysokość, z której doszło do upadku osoby poszkodowanej $(h)$.

Do oceny stanu bezpieczeństwa pracy na stanowiskach pracy z wykorzystaniem rusztowań budowlanych zaproponowano cząstkowe współczynniki możliwości zaistnienia sytuacji niebezpiecznej oraz ogólny współczynnik zagrożenia. Zaproponowany cząstkowy współczynnik zagrożenia dla rusztowań $\left(W_{j}\right) \mathrm{w}$ zależności od analizowanych parametrów można obliczyć za pomocą wzoru:

$$
W_{j}=\frac{i_{j}}{l_{j}}
$$

gdzie:

$W_{j}$ - cząstkowy współczynnik zagrożenia dla analizowanego parametru $j=\{w, g, r, t, h\}$,

$i_{j}-i$-ta liczba osób poszkodowanych dla analizowanego $j$-tego parametru,

$l_{j}$ - liczba wszystkich osób poszkodowanych $(\Sigma i)$ dla analizowanego $j$-tego parametru.

W powyższym wzorze cząstkowe współczynniki zagrożenia odniesione zostały do liczby wszystkich analizowanych wypadków przy pracy. 
Ogólny współczynnik zagrożenia $\left(W_{z}\right)$ otrzymuje się za pomocą poniższego wzoru:

$W_{z}=\frac{\sum W_{j}}{5}$

gdzie:

$W_{z}$ - ogólny współczynnik zagrożenia,

$\Sigma W_{j}$ - suma cząstkowych współczynników zagrożenia $j=\{w, g, r, t, h\}$.

Na podstawie analizy protokołów kontroli, otrzymanych cząstkowych współczynników zagrożenia oraz ogólnego współczynnika zagrożenia i odniesienia otrzymanych wartości do oszacowanej populacji rusztowań budowlanych na obszarze poddanym analizie ( 5 województw Polski) opracowano formularz pozwalający na wstępne określenie stanu bezpieczeństwa rusztowania budowlanego $\mathrm{w}$ aspekcie możliwości wystąpienia sytuacji niepożądanej - wypadku przy pracy.

\section{ANALIZA DANYCH}

W tym rozdziale przedstawiono wyniki otrzymanych analiz dla badanych 5 parametrów wypadków przy pracy z udziałem rusztowań budowlanych otrzymanych w wyniku analizy 219 osób poszkodowanych w wypadkach przy pracy. W prowadzonych analizach zmianom ulegała liczebność grupy badawczej z uwagi na brak danych w protokołach kontroli. W związku z tym dla niektórych analiz odrzucano te wypadki, które nie posiadały analizowanego parametru.

\section{Wiek osoby poszkodowanej (w)}

W tabeli 1 przedstawiono liczbę osób poszkodowanych w zależności od wieku osoby poszkodowanej oraz cząstkowy współczynnik zagrożenia $\left(W_{w}\right)$. Analiza struktury wieku osób poszkodowanych w wypadkach przy pracy na stanowiskach pracy z wykorzystaniem rusztowań budowlanych przeprowadzona została na próbie 148 osób.

Obliczone wartości wskazują, że im większa wartość wyznaczonego cząstkowego współczynnika zagrożenia, tym większe niebezpieczeństwo pracy na rusztowaniu i możliwość wystąpienia wypadku przy pracy.

Zaskakująca dla autorów jest mała liczba osób poszkodowanych w grupie wiekowej 18-19 lat, która wyniosła 3 osoby. $\mathrm{Na}$ podstawie analizy literatury spodziewano się większej liczby poszkodowanych $\mathrm{w}$ tej grupie. Największa liczba zdarzeń wypadkowych w przedziale 40-49 zdaniem autorów ma związek z rutynowym podejściem pracowników do wykonywanych czynności zawodowych (nierzadko mających blisko 25-letnie doświadczenie zawodowe), obniżeniem zdolności psychomotorycznych w tym wieku. W grupie powyżej 60 . roku życia obserwuje się spadek liczby zdarzeń wypadkowych, co może wiązać się m.in. ze zmianą stanowiska pracy, $\mathrm{z}$ przejściem na emeryturę lub większym asekuranctwem w pracy.

\section{Godzina wypadku w której doszło do wypadku (g)}

W tabeli 2 zamieszczono liczbę osób poszkodowanych w zależności od godziny, w trakcie której doszło do wypadku przy pracy, oraz cząstkowy współczynnik

Tabela 1. Cząstkowy współczynnik zagrożenia dla parametru: wiek osoby poszkodowanej

Table 1. The partial factor of work safety for the parameter: age of the injured person

\begin{tabular}{lcccccc}
\hline \multirow{2}{*}{ Wyszczególnienie - Specification } & \multicolumn{5}{c}{ Wiek osoby poszkodowanej - Age of the injured person } \\
\cline { 2 - 7 } & $18-19$ & $20-29$ & $30-39$ & $40-49$ & $50-59$ & $>60$ \\
\hline $\begin{array}{l}\text { Liczba osób poszkodowanych } \\
\text { Number of injured person }\left(i_{w}\right)\end{array}$ & 3 & 33 & 30 & 35 & 41 & 6 \\
\hline $\begin{array}{l}\text { Cząstkowy współczynnik zagrożenia } \\
\text { Partial factor of work safety }\left(W_{w}\right)\end{array}$ & 0,02 & 0,22 & 0,20 & 0,24 & 0,28 & 0,04 \\
\hline
\end{tabular}


Sawicki, M., Szóstak, M. (2019). Ocena stanu bezpieczeństwa pracy na rusztowaniach budowlanych na podstawie protokołów kontroli powypadkowe. Acta Sci. Pol. Architectura 18 (2), 51-59, DOI: 10.22630/ASPA.2019.18.2.22

Tabela 2. Cząstkowy współczynnik zagrożenia dla parametru: godzina wypadku

Table 2. The partial factor of work safety for the parameter: the time of the accident

\begin{tabular}{|c|c|c|c|c|c|c|c|c|c|c|c|c|}
\hline \multirow{2}{*}{$\begin{array}{l}\text { Wyszczególnienie } \\
\text { Specification }\end{array}$} & \multicolumn{12}{|c|}{ Godzina wypadku - Time of the accident } \\
\hline & $\begin{array}{l}07: 00- \\
-07: 59\end{array}$ & $\begin{array}{l}08: 00- \\
-08: 59\end{array}$ & $\begin{array}{l}09: 00- \\
-09: 59\end{array}$ & $\begin{array}{l}10: 00 \\
-10: 59\end{array}$ & $\begin{array}{l}11: 00 \\
-11: 59\end{array}$ & $\begin{array}{l}12: 00 \\
-12: 59\end{array}$ & $\begin{array}{l}13: 00- \\
-13: 59\end{array}$ & $\begin{array}{l}14: 00- \\
-14: 59\end{array}$ & $\begin{array}{l}15: 00- \\
-15: 59\end{array}$ & $\begin{array}{l}16: 00- \\
-16: 59\end{array}$ & $\begin{array}{l}17: 00 \\
-17: 59\end{array}$ & $\begin{array}{l}18: 00- \\
-06: 59\end{array}$ \\
\hline $\begin{array}{l}\text { Liczba osób } \\
\text { poszkodowanych } \\
\text { Number of injured } \\
\text { person }\left(i_{g}\right)\end{array}$ & 12 & 19 & 26 & 17 & 16 & 18 & 13 & 27 & 19 & 11 & 3 & 4 \\
\hline $\begin{array}{l}\text { Cząstkowy } \\
\text { współczynnik } \\
\text { zagrożenia } \\
\text { Partial factor of } \\
\text { work safety }\left(W_{g}\right)\end{array}$ & 0,06 & 0,10 & 0,14 & 0,09 & 0,09 & 0,10 & 0,07 & 0,15 & 0,10 & 0,06 & 0,02 & 0,02 \\
\hline
\end{tabular}

zagrożenia $\left(W_{g}\right)$. Analiza pory dnia roboczego powstania wypadku przy pracy przeprowadzona została na próbie 185 osób.

Dla analizowanych danych dużą wartość cząstkowego współczynnika zagrożenia $\left(W_{g}\right)$ odnotowano dla 2 przedziałów czasowych, tj.: między 09:00 a 09:59 $\left(W_{g}=0,14\right)$ oraz między 14:00 a 14:59 $\left(W_{g}=0,15\right)$. Wynika to z częściowego rozluźnienia pracowników chwilę przed przerwą śniadaniową, a także przed zakończeniem pracy (Sawicki i Szóstak, 2018; Sawicki, Szóstak, Wójcicki, Sawicki i Grosel, 2018). Należy zauważyć, że pracownicy wykonujący w tych przedziałach czasowych prace budowlane na rusztowaniach są szczególnie narażeni na możliwość wystąpie- nia zdarzeń wypadkowych, dlatego osoby kierujące pracą (kierownicy robót, majstrowie) powinny w tych godzinach szczególnie zintensyfikować nadzór nad prowadzonymi pracami.

\section{Rodzaj prowadzonych robót $(r)$}

Tabela 3 zawiera dane dotyczące rodzaju prowadzonych robót, w trakcie których doszło do wypadku, oraz cząstkowy współczynnik zagrożenia $\left(W_{r}\right)$.

Do wypadków przy pracy z udziałem rusztowań budowlanych najczęściej dochodziło podczas wznoszenia nowych obiektów budowlanych $\left(W_{r}=0,50\right)$. To podczas tych robót budowlanych najczęściej dochodzi do wypadków przy pracy.

Tabela 3. Cząstkowy współczynnik zagrożenia dla parametru: rodzaj prowadzonych robót

Table 3. The partial factor of work safety for the parameter: the type of works

\begin{tabular}{|c|c|c|c|c|c|}
\hline \multirow[b]{2}{*}{ Wyszczególnienie - Specification } & \multicolumn{5}{|c|}{ Rodzaj prowadzonych robót - Type of works } \\
\hline & $\begin{array}{c}\text { roboty } \\
\text { budowlane } \\
\text { construction } \\
\text { works } \\
\end{array}$ & $\begin{array}{c}\text { roboty } \\
\text { remontowe } \\
\text { renovation } \\
\text { worsks } \\
\end{array}$ & $\begin{array}{c}\text { montaż } \\
\text { rusztowania } \\
\text { installation of } \\
\text { scaffolding } \\
\end{array}$ & $\begin{array}{c}\text { demontaż } \\
\text { rusztowania } \\
\text { dismantling } \\
\text { scaffolding } \\
\end{array}$ & $\begin{array}{l}\text { ogółem } \\
\text { all }\end{array}$ \\
\hline $\begin{array}{l}\text { Liczba osób poszkodowanych ogółem } \\
\text { Number of injured person - all accidents }\left(i_{r}\right)\end{array}$ & 110 & 83 & 12 & 14 & 219 \\
\hline $\begin{array}{l}\text { Liczba osób poszkodowanych - śmiertelne } \\
\text { Number of injured person - fatal accidents }\left(i_{r}\right)\end{array}$ & 22 & 15 & 1 & 3 & 41 \\
\hline $\begin{array}{l}\text { Liczba osób poszkodowanych - ciężkie } \\
\text { Number of injured person - severe body injures }\left(i_{r}\right)\end{array}$ & 56 & 42 & 6 & 7 & 111 \\
\hline $\begin{array}{l}\text { Liczba osób poszkodowanych - lekkie } \\
\text { Number of injured person - minor body injuries }\left(i_{r}\right)\end{array}$ & 32 & 26 & 5 & 4 & 67 \\
\hline $\begin{array}{l}\text { Cząstkowy współczynnik zagrożenia } \\
\text { Partial factor of work safety }\left(W_{r}\right)\end{array}$ & 0,50 & 0,38 & 0,06 & 0,06 & \\
\hline
\end{tabular}


Sawicki, M., Szóstak, M. (2019). Ocena stanu bezpieczeństwa pracy na rusztowaniach budowlanych na podstawie protokołów kontroli powypadkowe. Acta Sci. Pol. Architectura 18 (2), 51-59, DOI: 10.22630/ASPA.2019.18.2.22

Typ rusztowania na którym doszło do wypadku (t) W tabeli 4 przedstawiono liczbę osób poszkodowanych w zależności od typu rusztowania, na którym doszło do wypadku, oraz cząstkowy współczynnik zagrożenia $\left(W_{t}\right)$. Analiza typu rusztowania przeprowadzona została na próbie 194 osób.

Na podstawie otrzymanych danych do wypadków przy pracy najczęściej dochodziło $\mathrm{z}$ rusztowań typu warszawskiego $\left(W_{t}=0,34\right)$ oraz z rusztowań ramowych, które stanowiły ponad 33\% wszystkich wypadków z udziałem rusztowań budowlanych. Podczas doboru rusztowań budowlanych jako czynnika mate- rialnego związanego z czynnością wykonywana przez poszkodowanego należy zwrócić szczególną uwagę na bezpieczeństwo pracy tych konstrukcji. $Z$ otrzymanych wartości cząstkowego współczynnika zagrożenia można zauważyć, że rusztowania warszawskie oraz ramowe są konstrukcjami, na których dochodzi częściej do wypadków niż na innych typach rusztowań. Powyższe stwierdzenie może wynikać z tego, że na polskich budowach częściej korzysta się z tego typu konstrukcji (rusztowań warszawskich, ramowych, systemowych) niż z innych rozwiązań, np.: rusztowań modułowych, rurowych, podwieszanych.

Tabela 4. Cząstkowy współczynnik zagrożenia dla parametru: typ rusztowania

Table 4. The partial factor of work safety for the parameter: type of scaffoldings

\begin{tabular}{lccccccc}
\hline $\begin{array}{l}\text { Wyszczególnienie } \\
\text { Specification }\end{array}$ & \multicolumn{6}{c}{ Typ rusztowania - Type of scaffoldings } \\
\cline { 2 - 8 } & $\begin{array}{c}\text { systemowe } \\
\text { system }\end{array}$ & $\begin{array}{c}\text { ramowe } \\
\text { frame }\end{array}$ & $\begin{array}{c}\text { modułowe } \\
\text { modular }\end{array}$ & $\begin{array}{c}\text { rurowe } \\
\text { tubular }\end{array}$ & $\begin{array}{c}\text { przejezdne } \\
\text { mobile }\end{array}$ & $\begin{array}{c}\text { warszawskie } \\
\text { Warsaw scaffolding }\end{array}$ & $\begin{array}{c}\text { podwieszane } \\
\text { suspended }\end{array}$ \\
\hline $\begin{array}{l}\text { Liczba osób poszkodowanych } \\
\text { Number of injured person }\left(i_{t}\right)\end{array}$ & 31 & 64 & 3 & 5 & 24 & 65 & 2 \\
\hline $\begin{array}{l}\text { Cząstkowy współczynnik zagrożenia } \\
\text { Partial factor of work safety }\left(W_{t}\right)\end{array}$ & 0,16 & 0,33 & 0,02 & 0,03 & 0,12 & 0,34 & 0,01 \\
\hline
\end{tabular}

\section{Wysokość z której doszło do upadku osoby poszkodowanej $(h)$}

W tabeli 5 zamieszczono liczbę osób poszkodowanych w zależności od wysokości, z której doszło do upadku osoby poszkodowanej, oraz cząstkowy współczynnik zagrożenia $\left(W_{h}\right)$.
Otrzymane dane wskazują, że im większa wysokość, na której prowadzone są prace budowlane, tym skutek wypadku jest poważniejszy w skutkach. Liczba wypadków o skutkach śmiertelnych i ciężkich rośnie wraz z wysokością, na której znajdują się pracownicy, natomiast możliwość wystąpienia wypadku lekkiego

Tabela 5. Cząstkowy współczynnik zagrożenia dla parametru: wysokość z której doszło do upadku

Table 5. The partial factor of work safety for the parameter: the height of scaffoldings on which accident occurred

\begin{tabular}{|c|c|c|c|c|c|}
\hline $\begin{array}{l}\text { Wysokość z której } \\
\text { doszło do upadku osoby } \\
\text { poszkodowanej } \\
\text { Height of scaffodlings } \\
\text { on which accident occurred }\end{array}$ & $\begin{array}{c}\text { Liczba osób } \\
\text { poszkodowanych } \\
\text { ogółem } \\
\text { Number of injured } \\
\text { person - all accidents } \\
\left(i_{h}\right)\end{array}$ & $\begin{array}{c}\text { Liczba osób } \\
\text { poszkodowanych } \\
\text { - śmiertelne } \\
\text { Number of injured } \\
\text { person - fatal } \\
\text { accidents } \\
\left(i_{h}\right) \\
\end{array}$ & $\begin{array}{c}\text { Liczba osób } \\
\text { poszkodowanych } \\
\text { - ciężkie } \\
\text { Number of injured } \\
\text { person - severe body } \\
\text { injures } \\
\left(i_{h}\right) \\
\end{array}$ & $\begin{array}{c}\text { Liczba osób } \\
\text { poszkodowanych } \\
\text { - lekkie } \\
\text { Number of injured } \\
\text { person - minor body } \\
\text { injurie } \\
\left(i_{h}\right) \\
\end{array}$ & $\begin{array}{c}\text { Cząstkowy } \\
\text { współczynnik } \\
\text { zagrożenia } \\
\text { Partial factor of } \\
\text { work safety } \\
\left(W_{h}\right) \\
\end{array}$ \\
\hline$<1 \mathrm{~m}$ & 8 & 0 & 1 & 7 & 0,04 \\
\hline$<1-2 \mathrm{~m})$ & 18 & 1 & 11 & 6 & 0,08 \\
\hline$<2-4 \mathrm{~m})$ & 80 & 5 & 43 & 32 & 0,37 \\
\hline$<4-6 \mathrm{~m})$ & 42 & 5 & 18 & 19 & 0,19 \\
\hline$<6-8 \mathrm{~m})$ & 23 & 7 & 13 & 3 & 0,11 \\
\hline$<8-10 \mathrm{~m})$ & 15 & 8 & 7 & 0 & 0,07 \\
\hline$<10-12 \mathrm{~m})$ & 12 & 6 & 6 & 0 & 0,05 \\
\hline$>12 \mathrm{~m}$ & 21 & 9 & 12 & 0 & 0,10 \\
\hline
\end{tabular}


maleje wraz $\mathrm{z}$ wysokością. Z otrzymanych danych wynika, że graniczną wysokością, dla której osoba poszkodowana może doznać tylko lekkich urazów, jest nie więcej niż $8 \mathrm{~m}$ (tj. upadek $\mathrm{z}$ co najwyżej 3. poziomu rusztowania budowlanego). Największa wartość cząstkowego współczynnika zagrożenia $(0,37)$ wystąpiła dla wypadków z wysokości 2-4 m, tj. z 1 . poziomu rusztowania. Najczęściej w wyniku upadku z rusztowań budowlanych dochodziło do ciężkich urazów (111 osób poszkodowanych, co stanowi ponad $50 \%$ wszystkich wypadków przy pracy).

\section{FORMULARZ WSTĘPNEJ OCENY BEZPIECZEŃSTWA RUSZTOWANIA BUDOWLANEGO}

Uzyskane wyniki analiz pozwoliły na opracowanie formularza wstępnej oceny bezpieczeństwa rusztowania budowlanego wykorzystującego zaproponowane cząstkowe współczynniki zagrożenia $\left(W_{j}\right)$, umożliwiającego wstępną ocenę prawdopodobieństwa zaistnienia zdarzenia wypadkowego na rusztowaniach budowlanych w odniesieniu do populacji badanych wypadków przy pracy $\left(W_{z}\right)$ oraz populacji rusztowań budowlanych. Populacja rusztowań budowlanych została oszacowana na podstawie otrzymanych wyników badań projektu „Model oceny ryzyka wystąpienia katastrof budowlanych, wypadków i zdarzeń niebezpiecznych na stanowiskach pracy z wykorzystaniem rusztowań budowlanych” („ORKWIZ”), zadania dotyczącego analizy ilościowo-jakościowej rusztowań budowlanych stosowanych w Polsce (Bucoń, Czarnigowska, Kmiecik i Robak, 2019). Formularz opracowano $\mathrm{w}$ formie elektronicznej za pomocą programu MS Excel. W tabeli 6 przedstawiono fragment formularza $\mathrm{w}$ zakresie proponowanych analizowanych parametrów wraz z przykładową analizą rusztowania budowlanego.

Na podstawie formularza wstępnej oceny bezpieczeństwa dla analizowanego rusztowania otrzymana wartość ogólnego współczynnika zagrożenia $\left(W_{z}\right)$ wyniosła 0,248 , co oznacza, że prawdopodobieństwo wystąpienia wypadku na analizowanym rusztowaniu, w odniesieniu do populacji zdarzeń wypadkowych, do których dotychczas doszło, przy założonych parametrach: typ rusztowania (rusztowanie warszawskie), wy- sokość, na której prowadzone będą prace (do $6 \mathrm{~m}$, tj. 2 poziomy robocze), wiek osób wchodzących w skład brygady roboczej (20-39 lat), rodzaj prowadzonych robót (roboty remontowe), czas pracy (07:00-15:00), wynosi $24,8 \%$.

W celu oszacowania populacji rusztowań budowlanych stosowanych w 5 badanych województwach Polski, w ciągu ostatnich 10 lat, wykorzystano otrzymane wyniki zliczania rusztowań budowlanych wykonywanych przez zespoły badawcze w ramach projektu „ORKWIZ”. Na podstawie wyznaczonych wskaźników liczby rusztowań budowlanych w przeliczeniu na $1 \mathrm{~km}^{2}$ w 5 badanych województwach określono badaną populację, która wyniosła 70000 rusztowań budowlanych w latach 2008-2017. Z oszacowanej wartości populacji rusztowań budowlanych w badanym okresie określono prawdopodobieństwo wystapienia wypadku przy pracy na stanowiskach, w których wykorzystuje się rusztowania budowlane. Prawdopodobieństwo to wyniosło $0,31 \%$, co oznacza, że na 1000 rusztowań budowlanych na co 3 . rusztowaniu dochodzi do wypadku przy pracy. Wartość współczynnika zagrożenia $\left(W_{j}\right)$ uwzględniającego oszacowaną populację rusztowań $(70000)$ w badanym okresie czasu, tj. 2008 -2017, dla badanego rusztowania (tab. 5) wyniosła 0,0008, co oznacza, że prawdopodobieństwo wystąpienia wypadku przy pracy na badanym rusztowaniu wynosi $0,08 \%$.

\section{PODSUMOWANIE}

Analiza osób poszkodowanych w wypadkach przy pracy w budownictwie $\mathrm{z}$ udziałem rusztowań budowlanych, do których doszło w Polsce na terenie 5 województw w latach 2008-2017, pozwoliła na określenie współczynników możliwości zaistnienia zagrożenia na stanowiskach pracy z wykorzystaniem rusztowań budowlanych, służących do oceny stanu bezpieczeństwa pracy na tego typu konstrukcjach.

W planowanych dalszych badaniach nad formularzem wstępnej oceny stanu bezpieczeństwa rusztowań budowlanych autorzy podejmą próbę uwzględnienia również pozostałych parametrów charakteryzujących rusztowania budowlane i pracowników na nich pracujących. Drugi kierunek badań dotyczy problematyki związanej z określeniem rzeczywistej populacji 
Sawicki, M., Szóstak, M. (2019). Ocena stanu bezpieczeństwa pracy na rusztowaniach budowlanych na podstawie protokołów kontroli powypadkowe. Acta Sci. Pol. Architectura 18 (2), 51-59, DOI: 10.22630/ASPA.2019.18.2.22

Tabela 6. Formularz wstępnej oceny stanu bezpieczeństwa rusztowań (fragment)

Table 6. Preliminary assessment form of safety of scaffoldings (fragment)

Formularz wstępnej oceny bezpieczeństwa rusztowania budowlanego - Preliminary assessment form of safety of scaffoldings

Typ rusztowania

Type of scaffolding
Cząstkowy współczynnik zagrożenia

Partial factor of work safety

$\left(W_{t}\right)$

Wybór użytkownika (wartość)

User selection (value) $W_{t} \quad \begin{gathered}\text { średnia ważona } \\ \text { weighted average }\end{gathered}$

\begin{tabular}{llc}
\hline Systemowe - System & 0,16 & - \\
\hline Ramowe - Frame & 0,33 & - \\
\hline Modułowe - Modular & 0,02 & - \\
\hline Rurowe - Tubular & 0,03 & - \\
\hline Przejezdne - Mobile & 0,12 & - \\
\hline Warszawskie - Warsaw & 0,34 & 0,34 \\
\hline Podwieszane - Suspended & 0,01 & -
\end{tabular}

Wysokość na której prowadzone będą prace na terenie budowy

Height of scaffoldings

Cząstkowy współczynnik zagrożenia

Partial factor of work safety

$W_{h}$

średnia ważona $\left(W_{h}\right)$ weighted average

mniej niż $1 \mathrm{~m} /$ less than $1 \mathrm{~m}$

0,04

\begin{tabular}{lll}
\hline$<1-2)$ & 0,08 & 0,08 \\
\hline$<2-4)$ & 0,37 & 0,37 \\
\hline$<4-6)$ & 0,19 & 0,19 \\
\hline$<6-8)$ & 0,11 & - \\
\hline$<8-10)$ & 0,07 & - \\
\hline$<10-12)$ & 0,05 & - \\
\hline powyżej 12 / more than $12 \mathrm{~m}$ & 0,10 & -
\end{tabular}

Wiek osób zatrudnionych do pracy na rusztowaniu Age of people working on the scaffoldings

\section{Cząstkowy współczynnik zagrożenia} Partial factor of work safety $\left(W_{w}\right)$

\begin{tabular}{lll}
\hline $18-19$ & 0,02 & - \\
\hline $20-29$ & 0,22 & 0,22 \\
\hline $30-39$ & 0,20 & 0,20 \\
\hline $40-49$ & 0,24 & - \\
\hline $50-59$ & 0,28 & - \\
\hline$>60$ & 0,04 & -
\end{tabular}

Rodzaj prowadzonych robót na terenie budowy Type of works on construction site
Cząstkowy współczynnik zagrożenia Partial factor of work safety $\left(W_{r}\right)$
$W_{r}$

średnia ważona weighted average

\begin{tabular}{llll}
\hline Roboty budowlane - Construction works & $\left(\boldsymbol{W}_{\boldsymbol{r}}\right)$ & 0,50 & $\mathbf{0 , 3 8}$ \\
\hline Roboty remontowe - Renovation works & $\mathbf{0 , 3 8}$ & $\mathbf{0 , 3 8}$ \\
\cline { 1 - 2 } Montaż rusztowania - Installation of scaffolding & 0,05 & 0,06 & \\
\hline Demontaż rusztowania - Dismantling scaffolding & & 0,06
\end{tabular}


Sawicki, M., Szóstak, M. (2019). Ocena stanu bezpieczeństwa pracy na rusztowaniach budowlanych na podstawie protokołów kontroli powypadkowe. Acta Sci. Pol. Architectura 18 (2), 51-59, DOI: 10.22630/ASPA.2019.18.2.22

Tabela 6. cd.

Table 6. cont.

\begin{tabular}{|c|c|c|c|}
\hline $\begin{array}{l}\text { Godzina w trakcie której prowadzone będą prace na } \\
\text { rusztowaniu } \\
\text { Working hours on scaffoldings }\end{array}$ & $\begin{array}{l}\text { Cząstkowy współczynnik zagrożenia } \\
\text { Partial factor of work safety } \\
\left(W_{g}\right)\end{array}$ & $W_{g}$ & $\begin{array}{c}\text { średnia ważona } \\
\text { weighted average }\end{array}$ \\
\hline 07.00-07:59 & 0,06 & 0,06 & \multirow{12}{*}{0,10} \\
\hline 08:00-08:59 & 0,10 & 0,10 & \\
\hline 09:00-09:59 & 0,14 & 0,14 & \\
\hline 10:00-10:59 & 0,09 & 0,09 & \\
\hline 11:00-11:59 & 0,09 & 0,09 & \\
\hline $12: 00-12: 59$ & 0,10 & 0,10 & \\
\hline 13:00-13:59 & 0,07 & 0,07 & \\
\hline 14:00-14:59 & 0,15 & 0,15 & \\
\hline $15: 00-15: 59$ & 0,10 & - & \\
\hline $16: 00-16: 59$ & 0,06 & - & \\
\hline 17:00-17:59 & 0,02 & - & \\
\hline 18:00-06:59 & 0,02 & - & \\
\hline SUMA - TOTAL & & \multicolumn{2}{|r|}{1,24} \\
\hline $\begin{array}{l}\text { Wartość ogólnego współczynnika zagrożenia } \\
\text { Value of overall factor of work safety } \\
\left(W_{j}\right)\end{array}$ & & \multicolumn{2}{|r|}{0,248} \\
\hline $\begin{array}{l}\text { Wartość wspólczynnika zagrożenia w odniesieniu do o } \\
(70 \text { 000) w badanym okresie czasu, tj. 2008-2017 } \\
\text { Value of factor of work safety in relation to the estimat } \\
(70 \text { 000) in the analysed period of time 2008-2017 } \\
\left(W_{z}\right)\end{array}$ & $\begin{array}{l}\text { acowanej populacji rusztowań } \\
\text { d population of scaffoldings }\end{array}$ & 0,0031 & 0,0008 \\
\hline
\end{tabular}

rusztowań budowlanych w Polsce, który pozwoliłby na określenie prawdopodobieństwa możliwości wystąpienia zdarzeń potencjalnie niebezpiecznych dla tego typu konstrukcji.

\section{PIŚMIENNICTWO}

Bucoń, R., Czarnigowska, A., Kmiecik, P., i Robak, A. (2019). Qualitative and Quantitative Assessment of Scaffolding Used in Polish Cities: Focus on Safety. IOP Conference Series: Materials Science and Engineering, 471 (112059), 1-10. DOI: 10.1088/1757$899 X / 471 / 11 / 112059$

Drozd, W. (2016). Characteristics of construction site in terms of occupational safety. Journal of Civil Engineering, Environment and Architecture, 33 (63), 165-172. DOI: $10.7862 / \mathrm{rb} .2016 .19$
Główny Urząd Statystyczny [GUS] (2018). Wypadki przy pracy w $2017 r$. Warszawa-Gdańsk.

Hoła, B. (2008). Modelowanie jakościowe i ilościowe wypadkowości $w$ budownictwie. Wrocław: Oficyna Wydawnicza Politechniki Wrocławskiej.

Hoła, B. (2016). Bezpieczeństwo pracy w procesach budowlanych. Wrocław: Oficyna Wydawnicza Politechniki Wrocławskiej.

Hoła, B., Nowobilski, T., Szer, I. i Szer, J. (2017). Identification of factors affecting the accident rate in the construction industry. Procedia Engineering, 208, 35-42. DOI: 10.1016/J.PROENG.2017.11.018

Jaafar, M. H., Arifin, K., Aiyub, K., Razman, M. R. i Kamaruddin, M. A. (2018). Human Element as the Contributing Factor Towards Construction Accidents from the Perspective of Malaysian Residential Construction Industry. In P. Arezes (Ed.), Advances in Safety Management and Human Factors. AHFE 2017. Advances 
in Intelligent Systems and Computing, vol. 604 (pp. 296-308). Cham: Springer. DOI: 10.1007/978-3-31960525-8_31

Jazayeri, E. i Dadi, G. (2017). Construction Safety Management Systems and Methods of Safety Performance Measurement: A Review. Journal of Safety Engineering, 6 (2), 15-28. DOI: 10.5923/j.safety.20170602.01

Sawicki, M. i Szóstak, M. (2018). Analysis of the dependence between the number of accidents at workplaces that involve scaffolding and changes in work efficiency. MATEC Web of Conferences, 174, 1-10.

Sawicki, M., Szóstak, M., Wójcicki, Z., Sawicki, W. i Grosel, J. (2018). Wypadki na rusztowaniach. Builder, 8, $82-85$.

Szóstak, M. (2018). Wpływ wybranych rodzajów robót na wypadkowość w budownictwie. Materiały Budowlane, 1 (10), 109-111. DOI: 10.15199/33.2018.10.33

\title{
ASSESSMENT OF THE SAFETY OF WORKING ON SCAFFOLDING BASED ON POST- -ACCIDENT PROTOCOLS
}

\begin{abstract}
The article attempts to assess the state of occupational safety at workstations that use construction scaffolding based on the proposed coefficients of the possibility of the occurrence of an occupational accident. The coefficients were determined on the basis of data that was collected from post-accident control protocols concerning occupational accidents involving construction scaffolding. The accidents took place in Poland in the construction industry and occurred in five voivodeships in the years 2008-2017. In the conducted research, the following parameters were analysed: age of the injured person, time in which the accident took place, type of carried out works, type of scaffolding on which the accident occurred, and the height from which the injured person fell. In order to assess the safety of work on scaffolding, partial coefficients of the possibility of the occurrence of a dangerous situation, as well as a general coefficient of a hazard, were proposed. The obtained results allowed a form in order to initially assess the safety of a construction scaffolding to be developed using the proposed partial hazard coefficients. This form enables the preliminary assessment of the probability of the occurrence of an accident on scaffolding to be conducted in relation to the population of occupational accidents and the population of construction scaffoldings.
\end{abstract}

Key words: construction scaffolding, occupational accidents, work safety 